\title{
Pendokumentasian Kegagalan pada Peralatan Main Liquid Fuel Pump GTG 1.1 dan Accessories Gear Train GTG 1.1 dengan Menggunakan Metode FMEA (Failure Mode \& Effect Analysis)
}

\author{
*Willy Noorasheed, Toni Prahasto, Munadi \\ Departemen Teknik Mesin, Fakultas Teknik, Universitas Diponegoro \\ Jl. Prof. Sudharto, SH., Tembalang-Semarang 50275, Telp. +62247460059 \\ *E-mail: willyrasheed8@gmail.com
}

\begin{abstract}
Maintenance of a company's assets is one of the main activities or actions undertaken with the aim of improving work safety and reduce the cost of expenses of a company. A company can be said to advance if the conditions of income from the company high and small expenditure. This is related to the activity of the maintenance of an asset. Unsuitable care triggers the damage or incidence of failure Mode of an asset. The level of damage and maintenance that is less appropriate to provide opportunities for damage that can be repaired or to be replaced. The high frequency of an asset that is damaged that requires a change to affect the financial condition of the company. Besides that, damage to an asset can also affect the production process that takes place at a company. So that the problem solved one solution that can overcome or reduce the level of damage to an asset that is doing the appropriate treatment. In this research will be an analysis related to the condition of an asset that will be susceptible to damage by using failure mode \& effect analysis (FMEA) method. in this method will be identified failure mode that occurs in the associated assets. The identification process will then be assessed according to the condition of the field assets. With these values it can be used to prioritize the assets to be carried out the maintenance action. The results of this study were obtained from the smallest frequency of excitation transformer (PPT) GTG 1.1, protection relay GTG 1.1, liquid fuel stop valve gTG 1.1, load compartment GTG 1.1 with a frequency of 52.3 weeks / failure.
\end{abstract}

Keyword: asset, frekuensi, failure mode \& effect analysis, failure mode

\begin{abstract}
Abstrak
Perawatan suatu asset perusahaan merupakan salah satu aktivitas atau tindakan utama yang dilakukan dengan tujuan meningkatkan keselamatan kerja serta menekan biaya pengeluaran dari suatu perusahaan. Suatu perusahaan dapat dikatakan maju apabila kondisi pemasukan dari perusahaan tinggi dan pengeluaran kecil. Hal ini berkaitan dengan aktivitas dari perawatan suatu asset. Perawatan yang tidak sesuai memicu kerusakan atau timbulnya modus kegagalan dari suatu asset. Besarnya tingkat kerusakan dan perawatan yang kurang sesuai memberikan peluang akan terjadinya kerusakan baik yang dapat diperbaiki maupun yang harus diganti. Tingginya frekuensi suatu asset yang mengalami kerusakan yang mengharuskan untuk dilakukan pergantian mempengaruhi kondisi keuangan dari perusahaan tersebut. Disamping hal tersebut kerusakan pada suatu asset juga dapat mempengaruhi proses produksi yang berlangsung pada suatu perusahaan tersebut. Maka agar masalah tersebut teratasi salah satu solusi yang mampu mengatasi atau mengurangi tingkat kerusakan pada suatu asset yaitu melakukan perawatan yang sesuai. Pada penelitian ini akan dilakukan analisa terkait kondisi suatu asset yang rawan akan mengalami suatu kerusakan dengan menggunakan metode failure mode \& effect analysis (FMEA). pada metode ini akan diidentifikasi mode kegagalan yang terjadi pada asset yang terkait. Proses identifikasi tersebut maka akan diberikan penilaian sesuai kondisi asset dilapangan. Dengan nilai tersebut maka dapat digunakan untuk memprioritaskan asset yang akan dilakukan tindakan perawatan. Hasil dari Penelitian ini didapatkan besar dari frekuensi terkecil excitation transformer (PPT) GTG 1.1, protection relay GTG 1.1, liquid fuel stop valve GTG 1.1, load compartment GTG 1.1 dengan memiliki frekuensi sebesar 52.3 minggu/ kegagalan.
\end{abstract}

Kata kunci: asset, frekuensi, failure mode \& effect analysis, failure Mode

\section{Pendahuluan}

Perawatan asset perusahaan merupakan suatu bentuk kegiatan yang memiliki tujuan atau output dengan menghasilkan atau menjaga suatu asset (peralatan) supaya dapat bekerja atau beroperasi dangan baik dan lancar. Disamping hal tersebut perawatan asset ini dapat digunakan untuk menekan biaya pengeluaran dari perusahaan yang digunakan untuk mengganti atau melakukan perbaikan terhadap asset yang mengalami kerusakan. Sehingga kegiatan produksi dapat berjalan dengan sesuai harapan dan tidak terganggu. Perawatan asset sendiri memiliki 2 jenis yaitu meliputi preventive maintenance dan 
corrective maintenance. Preventive maintenance adalah perawatan asset yang dilakukan jauh jauh hari sebelum asset tersebut mengalami kerusakan berat yang harus ditangani atau diselesaikan dengan overhaul. Overhaul merupakan perbaikan yang dilakukan terhadap suatu asset sehingga asset tersebut dapat kembali seperti kondisi baru kembali. Dengan adanya preventive maintenance diharapkan dapat memperpanjang umur atau tool life dari suatu asset. Sedangkan corrective maintenance merupakan kegiatan perawatan asset yang dilakukan saat suatu asset mengalami kerusakan atau gangguan sehingga tidak dapat berfungsi atau beroperasi dengan baik dan lancar. Kondisi dilapangan sendiri banyak asset yang mendapatkan perawatan tidak secara optimal maupun efektif sehingga banyak terjadinya kegagalan yang menimpa baik suatu system maupun suatu peralatan. Apabila hal ini dilakukan secara kontinyu maka dapat mempengaruhi kondisi peralatan atau asset yang digunakan serta dapat menambah beban pengeluaran bagi perusahaan. Maka dari itu pada penelitian ini berfokus pada penggunaan metode perawatan failure mode \& effect analysis.

Faillure mode and effect analysis (FMEA) adalah suatu analisa yang digunakan untuk menggambarkan kondisi suatu asset. Dalam faillure mode effect and effect analysis (FMEA) terdapat beberapa informasi yang dapat digunakan untuk melakukan tindakan perawatan terhadap asset. Informasi yang didapat meliputi penyebab kegagalan yang menimpa asset, frekuensi asset mengalami kerusakan, tingkat darurat suatu asset yang mengalami gangguan atau kerusakan dan lain lain.

Tujuan dari penelitian ini terdiri atas beberapa point dimulai dengan mengetahui tahapan dalam melakukan pendokumentasian suatu kegagalan dengan menggunakan metode FMEA lalu mengetahui besar frekuensi yang dihasilkan dari beberapa peralatan yang terkait, kemudian dapat menentukan peralatan mana yang sering mengalami kegagalan dan yang terakhir adalah dapat mengetahui kegagalan yang terjadi untuk peralatan main liquid fuel pump GTG 1.1 pada pressure relief valve dan pada accessories gear train GTG 1.1 pada pinion gear.

\section{Material dan metode penelitian}

Penelitian dilakukan dengan menggunakan metode FMEA yang dibantu dengan aplikasi tools.profmea.com. metode penelitian dimulai dengan dilakukannya studi literatur terkait sistem yang akan dianalisa. Langkah selanjutnya berupa review sistem dan pengumpulan data. Setelah data yang terkait dengan penelitian didapat maka langkah berikutnya melakukan pengolahan secara langsung dengan menggunakan aplikasi tools.profmea.com. dimana aplikasi pendukung ini mampu mempermudah kinerja dalam membuat dokumen lembar FMEA. Informasi yang dikumpulkan sebelumnya diinputkan dalam aplikasi ini mulai dari profil perusahaan, sistem, subsistem, komponen dan lain lain. Setelah diinput kita dapat secara langsung eksport dan dihasilkan lembar dokumen FMEA. Aplikasi ini memiliki beberapa keunggulan salah satunya yaitu dengan menggunakan aplikasi ini maka dapat membantu dalam melakukan validasi atau pengolahan terhadap informasi FMEA kepada perusahaan. Sehingga penggunaan aplikasi protech FMEA ini dalam melakukan penyusunan sebuah dokumen lembar kerja FMEA dari suatu asset perusahaan dapat dilakukan secara efektif. Untuk tampilan beranda dari aplikasi tools.profmea.com dapat dilihat pada Gambar 1.

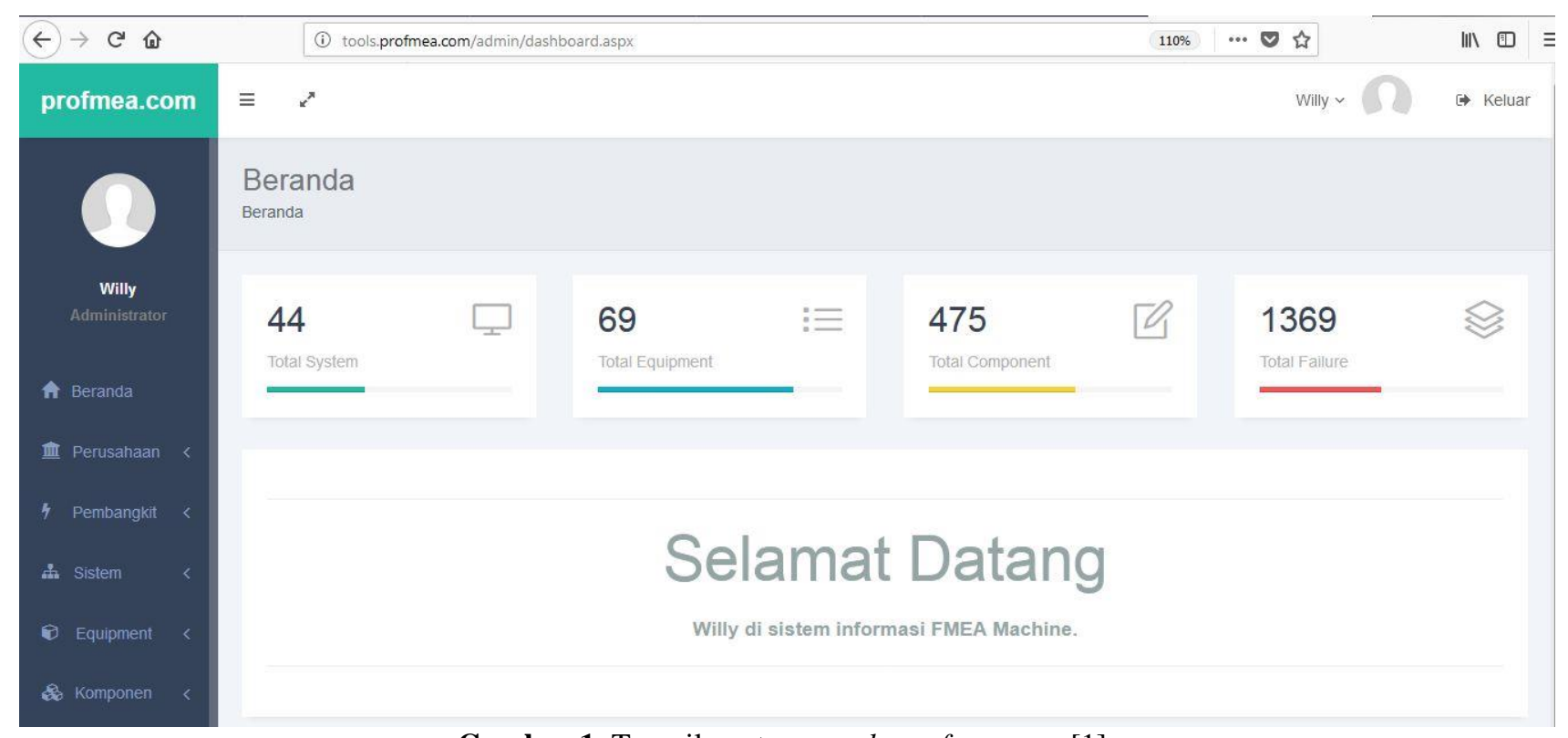

Gambar 1. Tampilan utama tools.profmea.com [1]

\section{Hasil dan pembahasan}

Hasil yang didapat pada pengerjaan penelitian ini berupa nilai frekuensi dari masing masing peralatan yang terpilih dan dokumen lembar kerja untuk peralatan main liquid fuel pump GTG 1.1. Nilai dari frekuensi yang didapat dari proses analisa akan dipertimbangkan untuk diinputkan dalam dokumen lembar kerja FMEA yang disusun dalam 2 tahap. Kemudian untuk proses serta tahapan-tahapan dalam pengerjaan penelitian ini akan disusun secara detail dalam sebuah laporan penelitian. 
Analisa tahap 1 \& 2 FMEA main liquid fuel pump GTG 1.1 - pressure valve

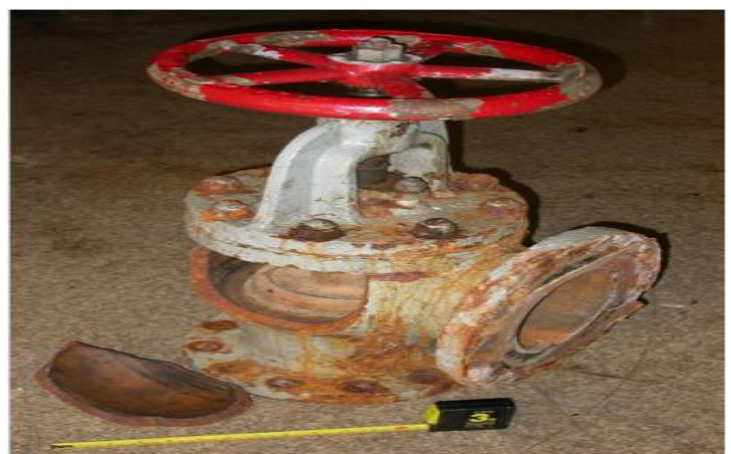

(a)

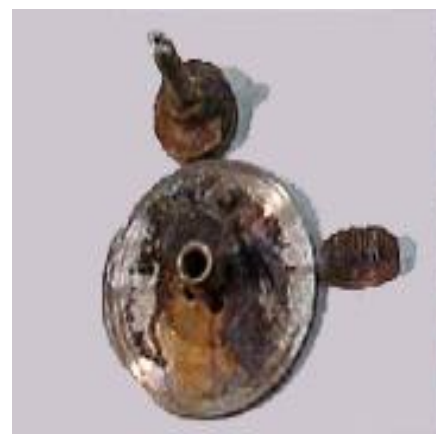

(b)

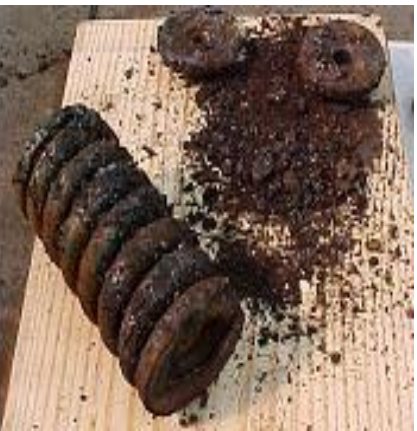

Gambar 2. (a) Kepatahan pada pressure relief valve [2], dan (b) Kebocoran pada pressure relief valve [2]

Gambar 2 (a) dan 2 (b) merupakan failure mode dari peralatan main liquid fuel pump GTG 1.1 pada komponen pressure relief valve. Gambar 2 (a) menunjukkan pressure relief valve mengalami kepatahan akibat adanya korosi yang merambat hampir seluruh permukaan valve sehingga berpotensi menimbulkan retakan yang kemudian seiring berjalannya waktu akan mengalami kepatahan [2]. Hasil analisa tahap 2 pada kegagalan diberikan penilaian berdasarkan 3 parameter yang meliputi severity, occurrence dan detection sebesar 5, 2, dan 4. Sedangkan Gambar 2 (b) menunjukkan terjadinya kebocoran yang dialami pressure relief valve yang ditimbulkan akibat adanya kotoran atau kandungan material yang menempel sehingga katup mengalami kebocoran dan hal ini dapat berpotensi merusak pressure relief valve dan mempengaruhi kerusakan pada komponen lainnya [3]. Untuk penilaian pada kegagalan yang kedua ini sebesar 5, 2, dan 4.

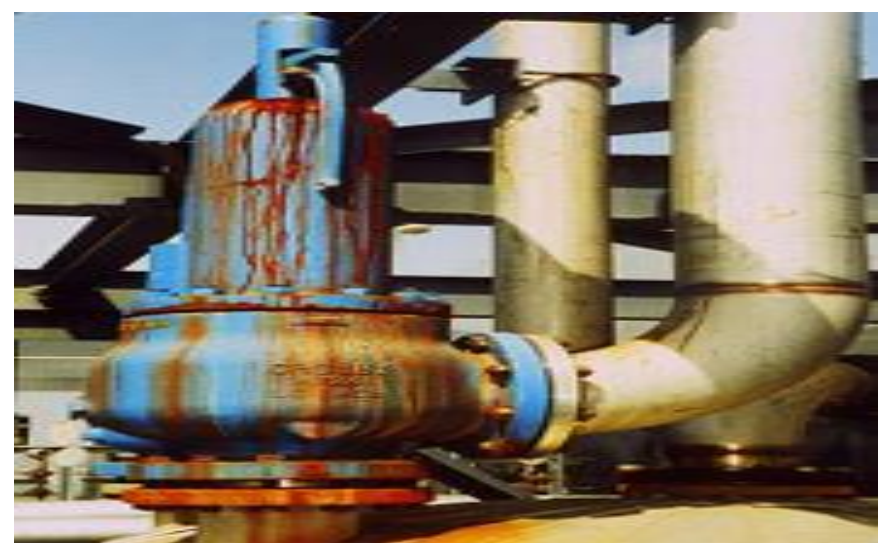

Gambar 3. Kepatahan pada pressure relief valve [4]

Untuk failure mode yang terakhir pada komponen pressure relief valve yaitu katup mudah terbuka. Keadaan ini diakibatkan kondisi pelapisan yang mudah terkelupas serta kondisi valve yang korosi, kotor. Hal ini akan meningkatkan laju korosi serta berpotensi membuat valve mengalami kebocoran bahkan mengalami kerusakan [5]. Agar lebih jelas dapat dilihat pada Gambar 3. Untuk kegagalan ini memiliki penilaian sebesar 4,3 dan 5.

\subsection{Analisa tahap $1 \& 2$ FMEA accessories gear train GTG 1.1 - pinion gear}

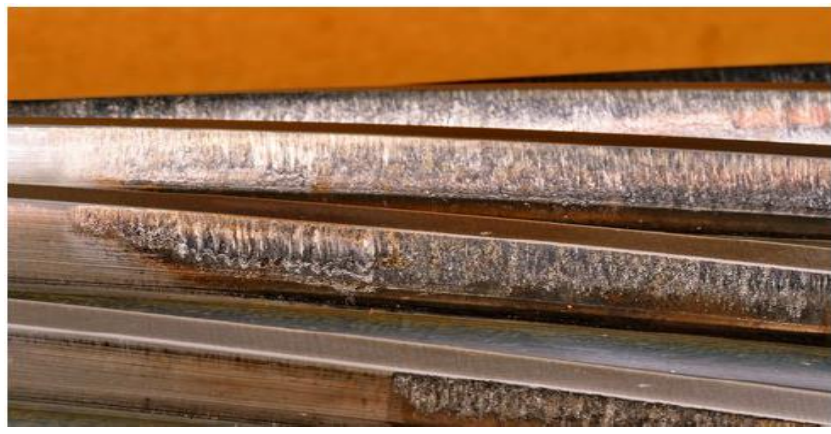

(a)

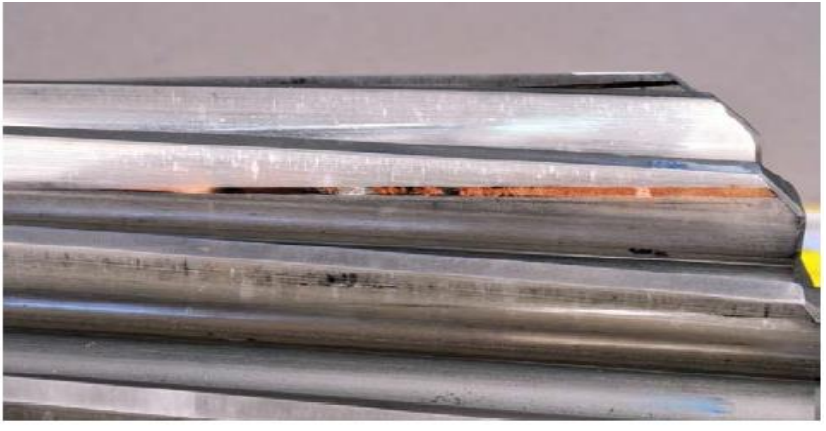

(b)

Gambar 4. (a) Scuffing pada pinion gear [6], dan (b) Freeting corrosion [6] 
Pada penelitian ini ditemukan 9 buah mode kegagalan yang memiliki kemungkinan terjadi pada komponen pinion gear. Gambar 4 (a) menunjukkan kegagalan scuffing. Kegagalan ini disebabkan pelumasan yang tidak sesuai dan tingginya frekuensi berkontaknya permukaan teeth gear [7]. Untuk penilaian dari mode kegagalan ini sebesar 5, 2 , dan 3. Kegagalan selanjutnya yaitu freeting corrosion yang bisa dilihat pada Gambar 4 (b) diatas. Kegagalan ini dipengaruhi keausan dan gesekan antar permukaan roda gigi. Mode kegagalan ini dapat menyebabkan korosi dan bending fatigue yang terjadi akibat besarnya keausan yang terjadi. Penilaian dari kegagalan ini berada pada kisaran 5, 3 dan 2

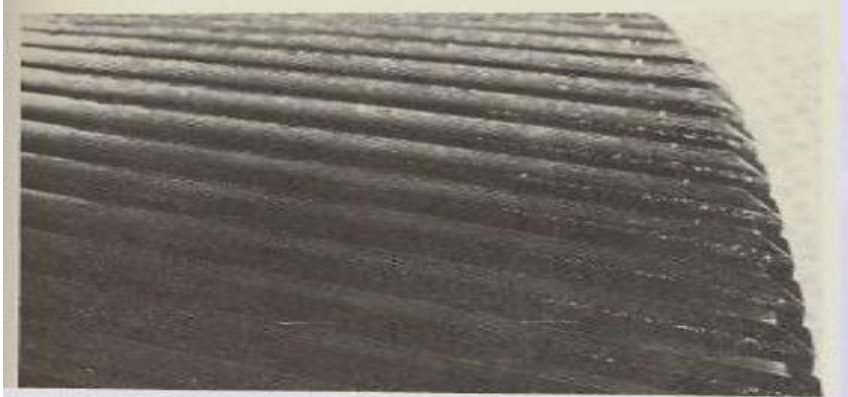

(a)

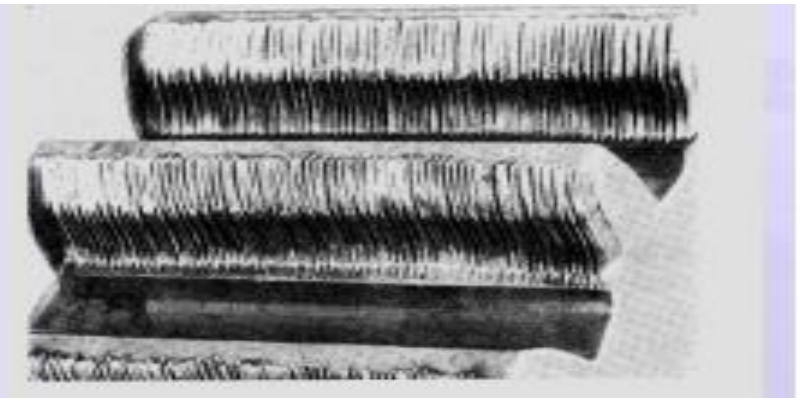

(b)

Gambar 5. (a) Mikropitting pada pinion gear [8], dan (b) Korosi wear pada pinion gear [8]

Mode kegagalan yang ketiga yaitu mikropitting. Mikropitting sendiri adalah kegagalan yang disebabkan telah terjadinya fatigue pada permukaan roda gigi hal ini dikarenakan pembebanan yang tinggi hingga melebihi surface fatigue strength dan terjadi berulang ulang. Sehingga berpotensi menyebabkan terjadi perubahan tekstur permukaan dari teeth roda gigi dan bahkan terbentuknya retakan [9]. Penilaian parameter dari kegagalan ini sebesar 5, 2, dan 3. Selanjutnya yaitu mode kegagalan korosi wear. Mode kegagalan ini dipengaruhi adanya kandungan zat kimia yang terdapat pada pelumas yang digunakan untuk mendinginkan. Sehingga dengan kandungan kimia tersebut permukaan roda gigi mudah mengalami korosi dan keausan. Mode kegagalan ini memiliki penilaian 5, 2, dan 3 dalam parameter yang digunakan dalam menentukan jumlah nilai RPN.

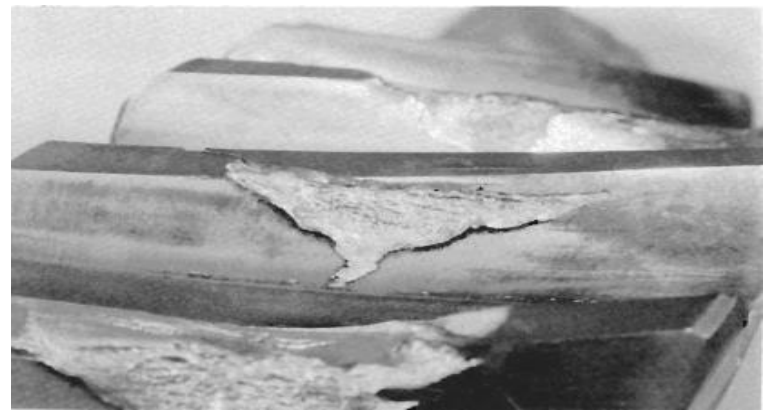

(a)

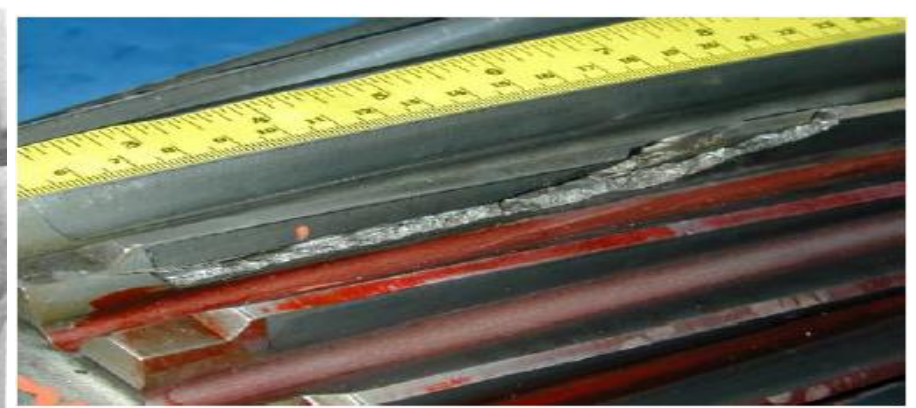

(b)

Gambar 6. (a) Spalling pada pinion gear [10], dan (b) Bending fatigue pada pinion gear [11]

Selanjutnya merupakan mode kegagalan spalling pada roda gigi. Mode kegagalan ini juga termasuk dalam kegagalan pitting namun berbeda dengan mikropitting. Kegagalan ini termasuk pada progressive pitting dimana pada kegagalan ini menyebabkan terjadinya surface fatigue bahkan hingga kepatahan hal ini lantaran terjadi dikarenakan distribusi tegangan yang ada pada bawah lapisan permukaan tidak merata [12]. Penilaian parameter dari kegagalan ini sebesar 4, 2 , dan 3. Kemudian mode kegagalan yang keenam yaitu bending fatigue yang dapat dilihat pada Gambar 6 (b). Pada Gambar 6 (b) terlihat bahwa teeth roda gigi mengalami patah dikarenakan bending fatigue terjadi secara berulang. Bending fatigue ini terbentuk dikarenakan telah timbulnya retakan atau crack yang sudah tercipta terlebih dahulu sehingga seiring berjalannya waktu maka akan memperbesar efek hingga terjadilah kepatahan. Mode kegagalan ini memiliki penilaian 6, 2, dan 3 dalam parameter yang digunakan dalam menentukan jumlah nilai RPN.

Kegagalan berikutnya adalah beakage pada pinion gear. Beakage ini terjadi dikarenakan terjadinya kegagalan saat berlangsungnya proses permesinan atau proses produksi. Untuk lebih jelas dapat dilihat pada Gambar 7 (a). Kegagalan ini berdampak pada teeth gear yang berpotensi mengalami fracture atau kepatahan. Dengan dampak seperti itu kegagalan memiliki nilai parameter 7, 2, dan 3. Selanjutnya adalah mode kegagalan plastic flow pada roda gigi. Plastic flow terbentuk disaat berlangsungnya operasi saat permukaan teeth gear berkontak gaya yang ditimbulkan saat kontak tersebut terlalu tinggi alhasil membuat roda gigi mengalami patahan atau defleksi. Untuk lebih jelas dapat dilihat pada Gambar 7 (b). Pada kegagalan ini diberikan penilaian parameter 6, 2, dan 3. Kemudian mode kegagalan scoring merupakan lanjutan dari kegagalan scuffing dimana scuffing yang terjadi telah menyebar hampir keseluruh permukaan. Hal ini terjadi lantaran 
tingginya temperatur oli yang digunakan proses pedinginan serta terjadinya kegagalan saat pendinginan. Untuk bentuk atau tampilan saat gear mengalami scoring dapat dilihat pada Gambar 8. Apabila hal ini terus berlanjut maka akan berdampak perubahan fisik permukaan menjadi sedikit kasar bahkan dapat mengalami keretkan. Mode kegagalan ini memiliki penilaian 4, 2, dan 3 dalam parameter yang digunakan dalam menentukan jumlah nilai RPN

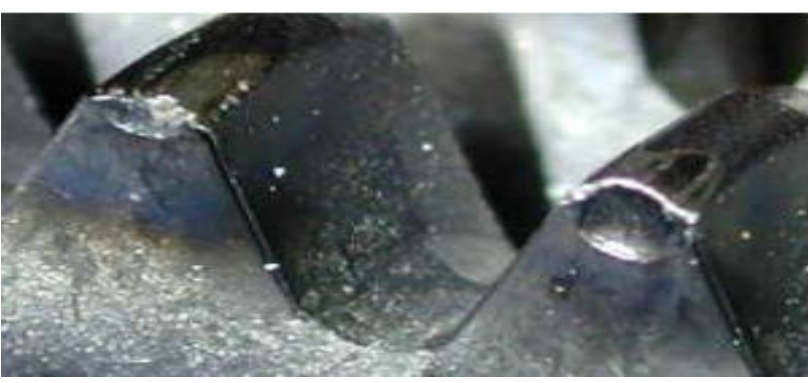

(a)

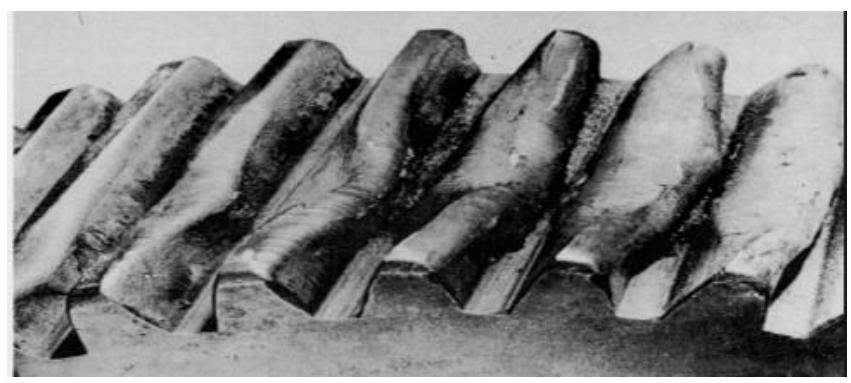

(b)

Gambar 7. (a) Beakage pada pinion gear [13], dan (b) Plastic flow pada pinion gear [14]

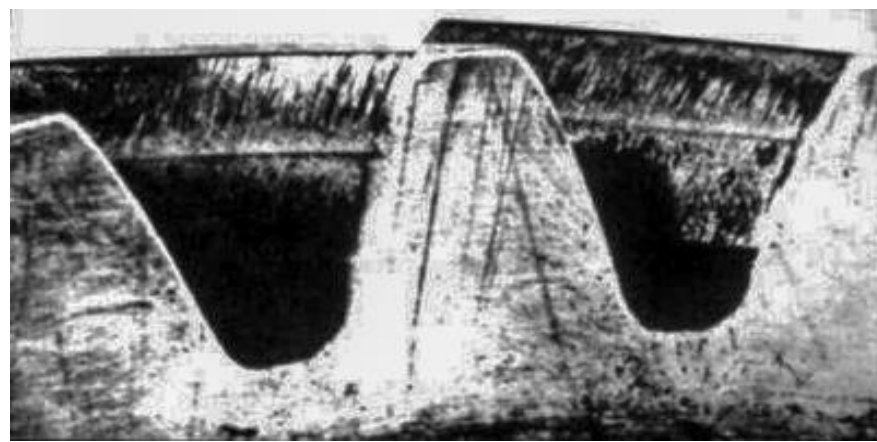

Gambar 8. Scoring pada pinion gear [15]

3.2 Analisa frekuensi - work order

\begin{tabular}{|c|c|c|c|c|c|c|c|c|}
\hline Work Order & Description & Work Type & Priority & Failure Class & Problem Code & Actual Start & Actual Finish & Status \\
\hline 472868 & $\begin{array}{l}\text { MR- } \\
\text { GTG } 1.1 \text { PEMELIHARAAN MAIN FUEL PUMP PF- } \\
1(4 \mathrm{~W})\end{array}$ & PM & 3 & & & & & WSCH \\
\hline 476837 & Cleaning \& Inspeksi Maghnetic Coupling & $\mathrm{OH}$ & 3 & & & 10/9/17 2:47 PM & & INPRG \\
\hline 476838 & Cleaning \& Inspeksi Main Fuel Pump & $\mathrm{OH}$ & 3 & & & 10/9/17 2:47 PM & & INPRG \\
\hline 476836 & Cleaning \& Inspeksi ACC Gear & $\mathrm{OH}$ & 3 & & & 10/9/17 2:47 PM & & INPRG \\
\hline 476835 & Bongkar Cover ACC Gear & $\mathrm{OH}$ & 3 & & & 10/9/17 2:47 PM & & INPRG \\
\hline 476834 & Persiapan Bongkar ACC Gear & $\mathrm{OH}$ & 3 & & & 10/9/17 2:47 PM & & INPRG \\
\hline 476825 & $\begin{array}{l}\text { Alignment Magnetic Coupling- } \\
\text { Main fuel Pump }\end{array}$ & $\mathrm{OH}$ & 3 & & & 10/9/17 2:47 PM & & INPRG \\
\hline 476818 & Pasang Main Fuel Oil Pump & $\mathrm{OH}$ & 3 & & & 10/9/17 2:47 PM & & INPRG \\
\hline 476800 & Bongkar Main Fuel Oil Pump & $\mathrm{OH}$ & 3 & & & 10/9/17 2:47 PM & & INPRG \\
\hline 476473 & Pemeliharaan Servo Valve LFBV dan IGV & $\mathrm{OH}$ & 3 & & & 10/9/17 2:44 PM & & INPRG \\
\hline 476447 & $\begin{array}{l}\text { Pemeliharaan Solenoid Valve Atomizing Air, I } \\
\text { GV \& Torque Converter }\end{array}$ & $\mathrm{OH}$ & 3 & & & 10/9/17 2:44 PM & & INPRG \\
\hline 477084 & $\begin{array}{l}\text { MR- } \\
\text { GTG } 1.1 \text { PEMELIHARAAN MAIN FUEL PUMP PF- } \\
1(4 \mathrm{~W})\end{array}$ & PM & 3 & & & 10/5/17 11:00 AM & 10/5/17 11:45 AM & CLOSE \\
\hline 421977 & $\begin{array}{l}\text { MR- } \\
\text { GTG } 1.1 \text { PEMELIHARAAN MAIN FUEL PUMP PF- } \\
1(4 \mathrm{~W})\end{array}$ & PM & 3 & & & 9/30/17 10:16 AM & 9/30/17 10:16 AM & CLOSE \\
\hline 472991 & $\begin{array}{l}\text { MR- } \\
\text { GTG } 1.1 \text { PEMELIHARAAN MAIN FUEL PUMP PF- } \\
1(4 \mathrm{~W})\end{array}$ & PM & 3 & & & 9/7/17 10:00 AM & $9 / 7 / 17$ 10:45 AM & CLOSE \\
\hline
\end{tabular}

Gambar 9. Work order main liquid fuel pump [16]

Work order adalah suatu dokumen yang berisi mengenai informasi berupa list atau daftar tindakan tindakan perawatan dari suatu asset. Pada work order ini terdiri dari deskripsi, work type, priority, failure class, problem code, actual start, actual finish dan status. Untuk lebih jelas dapat dilihat pada Gambar 9. Pada Gambar 9 terlihat tampilan dari dokumen work order. Penggunaan work order ini memiliki hubungan keterkaitan terhadap analisa pada FMEA. Dari work order 
ini dapat diketahui kegagalan yang menyebabkan kerusakan pada asset. Kegagalan yang ada pada work order tersebut dapat memberikan informasi mengenai frekuensi sebuah asset mengalami kerusakan.

\subsection{Analisa frekuensi - perhitungan frekuensi}

Frekuensi merupakan jumlah waktu yang dicapai suatu asset dalam mengalami satu kegagalan. Frekuensi tersebut digunakan untuk untuk menyusun suatu strategi perawatan sehingga dapat memperpanjang umur suatu asset dan mengurangi biaya yang dikeluarkan untuk melakukan perawatan. Frekuensi tersebut diketahui dari laju kegagalan dari asset tersebut. Laju kegagalan $(\lambda)$ adalah kecepatan atau kelajuan suatu asset mengalami suatu kegagalan. Berikut adalah persamaan dari laju kegagalan.

$$
\begin{gathered}
\lambda=\frac{r}{T(t)} \\
f=\frac{1}{\lambda}
\end{gathered}
$$

Keterangan :

$$
\begin{array}{ll}
\lambda & =\text { laju kegagalan } \\
\mathrm{r} & =\text { jumlah kegagalan } \\
\mathrm{T}(\mathrm{t}) & =\text { waktu } \\
f & =\text { frekuensi }
\end{array}
$$

Pada penelitian ini akan dilakukan analisa frekuensi pada beberapa peralatan yang berdasar pada data work order yang diberikan dari data perusahaan yaitu meliputi excitation transformer (PPT) GTG 1.1, protection relay GTG 1.1, collector GTG 1.1, liquid fuel stop valve GTG 1.1, main liquid fuel pump GTG 1.1, dan load compartment GTG 1.1. Hasil dari analisa perhitungan dapat dilihat pada diagram pie dibawah ini. disimpulkan untuk keempat peralatan tersebut memiliki rentan mengalami kegagalan setiap kurang lebih 52,3 minggu (13 bulan).

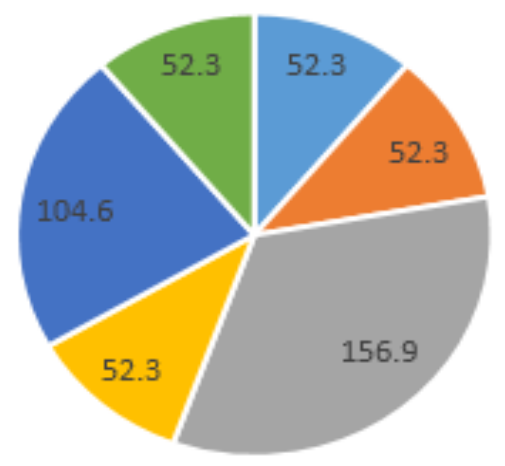

$$
\begin{aligned}
& \text { - Excitation Transformer (PPT) GTG } 1.1 \text { = Protection Relay GTG } 1.1 \\
& \text { = Collector GTG } 1.1 \text { = Liquid Fuel Stop Valve GTG } 1.1 \\
& \text { - Moin Liquid Fuel Pump GTG } 1.1 \text { = Load Compartment GTG 1.1 }
\end{aligned}
$$

Gambar 10. Hasil perhitungan frekuensi [1]

\section{Kesimpulan}

Dari penjelasan diatas dapat disimpulkan beberapa point. Pertama dalam melakukan analisa sebuah kegagalan dengan menggunakan metode FMEA diperlukan 2 tahapan. Pada tahap pertama akan dilakukan identifikasi potensi modus kegagalan, penyebab modus kegagalan, dampak yang ditimbulkan sebuah kegagalan dan metoda yang digunakan dalam mendeteksi kegagalan sedangkan untuk tahap kedua akan dilakukan penentuan besarnya nilai parameter severity, occurrence, dan detection yang digunakan untuk menentukan peralatan mana yang akan dipertimbangkan untuk dilakukan perawatan. Untuk yang kedua dari proses analisa perhitungan frekuensi yang dilakukan didapatkan untuk peralatan excitation transformer (PPT) GTG 1.1, protection relay GTG 1.1, liquid fuel stop valve GTG 1.1, dan load compartment GTG 1.1 memiliki nilai frekuensi yang sama kurang lebih sebesar 52.3 minggu (13 bulan) sedangkan collector GTG 1.1 memiliki frekuensi sebesar kurang lebih 156.9 minggu (39 bulan) dan untuk main liquid fuel 
pump GTG 1.1 kurang lebih Sebesar 104.6 minggu (26.15bulan). Lalu untuk yang ketiga dapat disimpulkan peralatan protection relay GTG 1.1, liquid fuel stop valve GTG 1.1, load compartment GTG 1.1 sering mengalami kerusakan karena yang memiliki frekuensi sebesar 52.3 minggu (13 bulan) dan kesimpulan yang terakhir kegagalan yang terdapat pada peralatan main liquid fuel pump khususnya pada peralatan pressure relief valve terdapat 3 buah yaitu kebocoran, kepatahan, dan katup mudah terbuka. Untuk peralatan accessories gear train pada komponen pinion Gear terdapat 9 buah kegagalan yang meliputi scuffing, micropitting, corrosion wear, bending fatigue, breakage, freeting corrosion, spalling, plastic flow dan scoring

\section{Daftar Pustaka}

[1] Profmea, tools.profmea.com. diakses 12, November, 2017.

[2] Ben-Daya, A., Reliability Centered Maintenance. www.researchgate.net/publication/282253338, diakses 28, November, 2017.

[3] Nanda, L.L., 2014, Analisis Risiko Kualitas Produk Dalam Proses Produksi Miniatur Bis Dengan Metode Failure Mode And Effect Analysis Pada Usaha Kecil Menengah Niki Kayoe, Surabaya, Gema Aktualita, Vol. 3, No. 2.

[4] Binley, R., The Pressure Relief Valve, coffeetime.wikidot.com/the-pressure-relief-valve. diakses 3, desember, 2017.

[5] Imansyah, L.N., 2014, Kajian Potensi Kerugian Akibat Penggunaan BBM Pada PLTG Dan PLTGU Di Sistem Jawa Bali, JURNAL TEKNIK POMITS, Vol. 1, No. 1.

[6] Sheng, S., 2014, Gearbox Typical Failure Modes, Detection and Mitigation Methods. National Renewable Energy Laboratory/National Wind Technology Center.

[7] Faizal, M.B., 2017, Analisis Performance Tm2500 Gas Turbine Generator Package Pltg X Pada Factory Test Dan Site Test. Bina Teknika, Vol. 13, No. 2.

[8] Gopinath, P., 2010, Machine Design II, Indian Institute of Technology Madras.

[9] Rausand, M., 2004, System Reliability Theory Models, Statistical Methods, and Applications, JOHN WILEY \& SONS, INC.

[10] Alban, L., 1985, Systematic Analysis of Gear Failures, Ohio, american society for metals.

[11] Blanchard, B., 1986, Logistics engineering and management. 3d ed. Prentice Hall.

[12] Winandi, A., 2012, Reliability Centered Maintenance Pada Pompa. Tugas akhir, Universitas Indonesia.

[13] Gear Failure, https://www.mechgrid.com/gear-failure.html. Diakses 21, Agustus, 2018.

[14] Gear the works run, https://gearsmechon.wordpress.com/plastic-flow/. Diakses 21, Agustus, 2018.

[15] Neale Consulting Engineers, Picture Of Some Typical Failure, http://www.tribology.co.uk/services/failureanalysis/how-to-diagnose-gear-failures/. Diakses 21, Agustus, 2018.

[16] Work Order. PT. Indonesia Power. Semarang. 2017. 